This item was submitted to Loughborough's Research Repository by the author.

Items in Figshare are protected by copyright, with all rights reserved, unless otherwise indicated.

\title{
Megaregions: foundations, frailties, futures
}

PLEASE CITE THE PUBLISHED VERSION

http://dx.doi.org/10.4337/9781782547907.00007

\section{PUBLISHER}

Edward Elgar @ John Harrison and Michael Hoyler

VERSION

AM (Accepted Manuscript)

LICENCE

CC BY-NC-ND 4.0

\section{REPOSITORY RECORD}

Harrison, John, and Michael Hoyler. 2019. "Megaregions: Foundations, Frailties, Futures". figshare. https://hdl.handle.net/2134/16584. 


\section{Megaregions: foundations, frailties, futures}

John Harrison and Michael Hoyler

\subsection{Introduction}

I hope that his own definition will be heeded; for the term is so awe-inspiring, and the phenomenon it describes so dramatic and novel, that it is very easy for misconceptions to take root. (Hecksher, 1964, p. vii)

August Hecksher is a name that is not necessarily instantly recognizable as being pivotal to the intellectual development of research on megaregions. Yet his words offer a profound insight into what lies at the heart of a critical research agenda for those of us whose interest in megaregions has brought us to contribute to this edited collection. When you consider the term Hecksher is alluding to is 'megalopolis', and that his quote appears in the foreword to the paperback edition of Jean Gottmann's classic 20thcentury urban geography and planning text Megalopolis: The Urbanized Northeastern Seaboard of the United States ${ }^{1}$, the relevance to contemporary work on megaregions starts to become clearer. His words take on added significance when you cast your eye over just some of the many terms that have been used over the last half century by geographers and planners to describe the phenomena of sprawling urbanized landscapes comprising clustered networks of cities: megalopolis ... archipelago economy, galactic city, string city, limitless city, endless city, liquid city, global city-region, world city- 
region, mega-city region, polycentric metropolis, new megalopolis, megapolitan region, metro region, polynuclear urban region, super urban area, super region ... megaregion.

The first question to consider, then, is why are we focusing on megaregions? After all, if you look back to Peter Taylor and Robert Lang's (2004) list of 50 names given to new metropolitan forms, the term megaregion is not present, while the most recently published 'dictionaries' in human geography both omit megaregion - though interestingly retain entries on 'megalopolis' (Castree et al., 2013; Gregory et al., 2009). Is the term megaregion simply less important than we think it is? Or perhaps the megaregion is as transient as some of the other concepts listed by Taylor and Lang ('cities a la carte', 'servurb' and 'sprinkler city') used to account for current or nearfuture urban form?

Our starting point is that despite considerable dispute over what the term might mean, an increasing number of commentators seem willing to agree that megaregions are important phenomena in globalization. One widely circulated story is that megaregions constitute globalization's new urban form. Here commentators appear convinced that the expansion of globalizing cities into larger city-regions is being superseded by trans-metropolitan landscapes comprising networked urban centres and their surrounding area. They appear captivated by a perception that what goes on in megaregions is foreboding our urban futures. And they seem assured that what occurs in megaregions constitutes the leading-edge of capitalist endeavour, driving competitiveness (Ross, 2009) and determining life opportunities (Florida, 2008). From its origins in the United States (Dewar and Epstein, 2007; Lang and Dhavale, 2005; Regional Plan Association, 2006), through to its parallels in European spatial planning (Faludi, 2009), and its spread and application to all manner of different geographical 
contexts (Yang, 2009; Pieterse, 2010; UN-Habitat, 2010; Weller and Boteller, 2013), there can be little doubt as to the importance currently being attached to the megaregion concept by its many advocates.

Nowhere is this intellectual buzz and appetite for megaregions more fervent than in the United States. Inspired by Gottmann's (1961) prediction that 'megalopolis' was the antecedent to a new spatial order that would emerge nationwide during the late 20th century, the beginning of the 21st century saw the Regional Plan Association (RPA) consider making their own statement on what they saw as the current and near-future 'megaregional' geography of the United States. Launched in 2005, America 2050 is that vision. It identifies 11 emerging megaregions as prototypes for balanced and sustainable growth across the United States during the first half of the 21st century (Figure 1.1).

Figure 1.1 America 2050's emerging US megaregions with areas of influence

$$
* * * \text { Insert Figure } 1.1 \text { here } * * *
$$

Source: $\quad$ America 2050 (2008). Reproduced by permission of the Regional Plan Association.

The background to America 2050 is significant. It is motivated by both internal and external pressures: internally, by the lack of federal action to identify and bring forward investments to reform the physical infrastructure (transport, energy, water) and secure America's future global economic competitiveness; externally, by what the RPA perceive their 'competitors' in Europe and Asia are already succeeding at by coupling specialized economic functions with integrated transportation modes to enable the efficient movement of workers, goods and information across extended geographical 
areas. What is compelling about the America 2050 map is it represents a belief that responding to this challenge, first, requires coordination at the megaregion scale, and second, can only be achieved with new investments in infrastructure development in and across these 11 megaregions. It is also an argument constructed from a series of normative assumptions about how our globalizing world is spatially configured.

If you believe the hype, megaregions are the spatial manifestation of economic activity and are fast 'becoming the new engines of global and regional economies' (UNHabitat, 2010b, p. 1). This argument is undergirded by a now familiar geoeconomic logic that in globalization, the largest and densest clusters of socioeconomic activity are those acting as the most important staging/strategic command posts, and therefore surging ahead, in todays' quicksilver global economy. From Florida's (2008) 'spiky world' riposte to Friedman's (2005) 'flat world' thesis, through to Glaeser's (2011) 'triumph of the city' or Brenner's (2013b) 'planetary urbanization', it is impossible to avoid the many reference points to the importance of urban economic processes in globalization. This is ably supported by a geopolitical logic that argues the scale and pace of urbanization in these locations is now so pervasive that new supra-local scales of urbanization are being created, which to function effectively require economic systems and political systems to be geographically aligned. One consequence of this is how urban expansion is seen to preclude localized solutions to the challenges posed by advancing globalization.

All of which leads proponents to claim that "urban mega-regions are coming to relate to the global economy in much the same way that metropolitan regions relate to national economies' (Florida et al., 2008, p. 460). This statement is significant, bold and challenging in equal measure: significant, because megaregions are the latest episode in 
the long-running political-economic drama that is the search for a post-national spatial/scalar fix for globalized capital accumulation and organizing (inter)national space economies; bold, because it upholds claims that there is an unbreakable logic linking megaregions (as space) and megaregionality (as process) with the most advanced elements of 21 st century globalization; and challenging, because why should megaregions be any different to the other spatial scale corpses, which, having achieved their own short-lived period of 'new regionalist' orthodoxy, came to be swept away in favour of the latest fashionable and soon-to-be dominant spatial policy tools (Harrison, 2007).

As early as 50 years ago, August Hecksher recognized this very concern. He observed how a spatial concept ('megalopolis') can generate such interest and excitement amongst academics and practitioners that its true value and meaning gets lost among the ensuing euphoria and paraphernalia that is its rise to orthodoxy ${ }^{2}$. It is precisely in the process of becoming a captured concept that Hecksher warns how easy it is for 'misconceptions' to take root. When a concept is captured it is taken away from the foundations upon which it has been constructed to be used in a deeply political way by actors in different contexts who wish to defend or challenge a particular viewpoint. The further a concept is distanced from its foundations, the greater the danger it will be misinterpreted, over-extended and inappropriately used by the actor(s) concerned. Those concepts which do rise to orthodoxy are arguably those at greatest risk of becoming what the social scientist Andrew Sayer (1992) famously categorized as a 'chaotic concept'. In this way, the rise of the megaregion prompts us to confront searching questions about the prospects for megaregionality to achieve the ambitious goals - enhanced competitiveness, accelerating investment in sustainable transportation 
infrastructure, creating liveable communities, smart planning - its academic and political proponents currently espouse. For within the current body of literature, no meaningful attempts have been made to discuss the foundations, frailties and futures of megaregional research.

This collection aims to instil some coherence into this debate by opening up the megaregion concept for critical scrutiny. Our starting point is that the rhetoric and cando bravado which currently surrounds megaregions has raced too far ahead of the sustained theoretical and rigorous empirical work needed to support many of the assertions, assumptions, claims and investments being made in the belief that megaregions do constitute globalization's new urban form. In particular, we examine the opportunities and challenges posed by current approaches to conceptualizing megaregions, megaregionality, and planning and governing at this scale. We wish to distinguish between the advances made by new perspectives to analysing megaregions and megaregionality, providing a clear indication of where these advances differ from the spurious claims made elsewhere in relation to megaregions.

To achieve this, the chapter is structured as follows. In the first section we aim to critically examine the foundations upon which the megaregion discourse has been constructed. In so doing, we conceptualize the position occupied by the megaregion in debates prior to the onset of globalization, and then discuss how the concept has been reawakened during globalization. The second section then explores four separate, yet interrelated, lines of argumentation which cut into the megaregional debate as it is currently constructed and form the basis for developing a more critical approach toward megaregional research. We conclude with some cautionary remarks about the challenges and opportunities for near-future megaregional research. 


\subsection{Foundations: from megalopolis to megaregions - a new' 'laboratory for urban growth'}

Despite the recent hype surrounding megaregions, the concept itself - or perhaps more accurately, the foundations upon which it is constructed - has a much longer history, the length of which remains the subject of some significant conjecture (see Baigent, 2004; Zhang, 2015). Nevertheless, for our purposes we are taking the beginning of the 20th century as starting point. This was a time when approximately seven per cent of the world's population could be considered urban and there were just sixteen cities with a population in excess of one million people (Harvey, 2000). It was also when the eminent Scottish planner and theorist Patrick Geddes (1915) first considered 'megalopolis', as both a concept and as a place. In this regard, Geddes actually predates Gottmann by almost 50 years in recognizing the potential for an urbanized corridor to extend along the northeastern seaboard of the United States.

In the end Geddes settled on minting the term 'conurbation' to develop his ideas about city evolution and the new urban configurations produced. In fact it was his contemporary, Lewis Mumford, who was to later pick up the term 'megalopolis' to define the fourth stage of six stages of city evolution (Mumford, 1938). The first three stages - 'eopolis' (village), 'polis' (city) and 'metropolis' (capital city) - chart the rise of the city. The final three stages - 'megalopolis' (a city of exaggerated size), 'tyrannopolis' (overexpansion causing rapid decline) and 'nekropolis' (city abandonment due to war and famine) - chart how great cities fall. For Mumford 'megalopolis' is the last vestige of urban development, the tipping point at which city 
development becomes over-development and the signal that a city is about to enter a period of (terminal) decline and disintegration.

Uniting Geddes and Mumford was their shared conviction that city expansion became unsustainable once a city reached the size of a megalopolis - though Geddes did stop someway short of Mumford's suggestions that unsustainable equalled irreversible fatality (Meller, 1993). For them and many others writing in the first half of the 20th century, cities were growing too fast and this meant megalopoli were cast in a negative light of the 'city as problem'. Gottmann's $(1957,1961)$ outlook on the coming megalopolises was the complete antithesis. In this way, Gottmann's labelling of the northeastern seaboard of the United States 'megalopolis' was hugely symbolic. Gottmann makes explicit his referring back over 2000 years to when the ancient Greeks planned for a new city-state (to be called Megalopolis), 'dream[ing] of a great future for it and hop[ing] it would become the largest of the Greek cities ...' and 'a symbol of the long tradition of human aspirations and endeavor' (Gottmann, 1961, p. 4). While Geddes and Mumford were fiercely critical of urban sprawl, Gottmann actively promoted a ferociously modernist and progressive view of the new urban form. Addressing the still dominant anti-modernist tradition inspired by Geddes and Mumford, Gottmann (1961, p. 13) goes to the length of asking 'Are people both in and out of this extraordinary region united in condemning it?' to emphasize his very different perspective on the emerging urban form.

Gottmann describes late-20th-century urban-economic expansion as promising social and economic fulfilment, enabling the 'masses' to access non-manual jobs, better housing, education and cultural offerings which were seen previously to be the exclusive domain of 'elites'. As a message detailing progress and improvement it 
quickly gained favour in the United States, particularly with those whose ancestors had left behind the European countryside for the North American city. Alongside this, urban policy elites, so used to hearing anti-urbanist accounts emphasizing the problems associated with the growth of cities, were 'flattered, if not surprised, to find their cities in the van of progress' (Baigent, 2004, p. 690).

Of course, this exposure brought with it a lot of attention. The term 'megalopolis' quickly became shorthand for all that is deemed progressive in (North American) urban planning. While this is not to say that Gottmann did not acknowledge the problems associated with megalopolis, it is noticeable that when so doing the argument veered toward the prophetic: 'Megalopolis stands indeed at the threshold of a new way of life, and upon [the] solution of its problems will rest civilization's ability to survive' (Gottmann, 1961, p. 16). In this way, megalopolis was to provide Gottmann and his contemporaries a 'laboratory for urban growth' as the full effect of globalizing forces began to take hold. Indeed, Gottmann's legacy arguably lives on in the present day focus on megaregions.

Often overlooked in Gottmann's work is the emphasis he placed on both form and function. We say overlooked because while Gottmann's work has traditionally been read for its contribution to informing debates around mapping and planning the evolving urban form, its structure and its anatomy, dig beneath the surface and you will find a putative relational economic geography with incipient ideas about the functioning of the urban system which he went on to develop and expand upon in subsequent works (Gottmann, 1976; Gottmann and Harper, 1990). Yet the dominant reading of Gottmann remains centred on his contribution to debates about the evolving urban form (see Lang and Knox, 2009; Morrill, 2006; Short, 2007; Vicino et al., 2007 for recent re- 
evaluations of the original megalopolis). This is significant because in the emerging body of work on megaregions, form-dominant approaches to megaregions appear more influential in the United States, whereas European accounts often adopt a more functionally-dominant perspective (see Section 1.3.2). In fact, what we have seen over the past two decades is an attempt to align the functional-dominance of the geoeconomic global city (region) literature with the form-dominance of traditional planning thought.

Table 1.1 From megalopolis to megaregions (and beyond)

$$
\text { *** Insert Table } 1.1 \text { here *** }
$$

Source: $\quad$ Authors

Table 1.1 presents key definitions of the major global urban-regional spatial configurations that have been identified in the literature. There are four points we take from this table. The first relates to the geographical context in which these spatial concepts have their intellectual origins and the specific purpose for which they were developed. Spatial concepts are not interchangeable. For us, there is a critical distinction that needs to be made, which helps define and delimit megaregions from other spatial concepts. Broadly speaking we distinguish between three types of urban-regional spatial configurations that relate to the global economy. While global city-regions, mega-city regions and metro(politan) regions relate to one urban system (comprising one or more cities), a megaregion comprises two or more interrelated urban systems, while planetary urbanization represents the reach of the global urban system across all geographic space (Figure 1.2). 
Figure 1.2 A typology of global urban-regional spatial configurations

*** Insert Figure 1.2 here $* * *$

Source: $\quad$ Authors

Meanwhile and somewhat related, second, we would argue there are distinctive North American and European perspectives on researching large-scale urban-regional configurations. American perspectives are still rooted in a form-dominant spatial planning tradition. In contrast, European perspectives, once steeped in discussions about urban spatial form (Dühr, 2007; Faludi, 2009; Kunzmann, 1996), are now more commonly associated with functionally-dominant global-city inspired networked approaches (Hall and Pain, 2006; Hoyler et al., 2008a; Pain and Van Hamme, 2014; Reades and Smith, 2014; Taylor et al., 2009). Distinguishing between these two traditions highlights how the type of megaregion that is constructed varies depending on whether you take rapid urbanization (form) or global economic integration (function) as your starting point for framing globalized urbanization (Harrison and Hoyler, 2014).

Third, the table neatly reflects Florida's (2008, p. 38) assertion that 'bigger and more competitive economic units - megaregions - have superseded cities as the real engines of the global economy'. This prompts us to confront the searching question about whether the newly identified megaregional spaces actually exist as planning, governance and economic spaces. Put bluntly: there has been little or no debate asking if megaregions are internally coherent spaces. One notable exception is the distinction Schafran (2014) makes between 'megaregional space' and 'spaces of the megaregion'. The latter relates to the unevenness of megaregionality within a pre-defined 
megaregion, drawing particular attention to those more localized spaces where it is actually played out most clearly. This is in stark contrast to the megaregion itself, which is constructed, mobilized and presented as a coherent space in order to achieve certain political outcomes.

This brings us round to our fourth and final point. Deploying the language of Allen et al. (1998, p. 2) 'there is no complete "portrait of a [mega]region". Moreover, "[mega]regions" only exist in relation to particular criteria. They are not "out there" waiting to be discovered, they are our (and others') constructions.' With this in mind, it is important to acknowledge that if the formative work on megaregions has concentrated on identifying where megaregional spaces and megaregionality are visible, the questions which are central to future agendas for research are who is constructing megaregional spaces, how are they constructing megaregional spaces, and why are they constructing megaregional spaces. The who and why questions require us to identify the actors involved in constructing megaregions politically, examine their motivations, and ask in whose interest their actions are being directed. It necessitates the need to consider which issues are being brought to the fore, and which are being pushed into the background, within a megaregion framing of development. The how question emphasizes the importance of the actual mechanisms through which megaregional space is constructed politically, in particular, the tactics and strategies employed by actors to advance their essential interests. It is in this way that we concur with the writings of the political geographer John Agnew, who in an intriguingly titled article 'Arguing with regions' reminds us that: 
[W]e should collectively invest in the plural of "regional logics", tailoring usage to the problems at hand, rather than in a singular logic that simply replaces the romance of the nation-state with an equally simple and one-size-fits-all alternative geographical unit of account such as ... the global city-region. (Agnew, 2013, p. 15)

While it is not difficult to envisage Agnew now replacing 'global city-region' with 'megaregion', it is what the quote signifies which is of importance here. Megaregions mean different things to different actors in different contexts, each with different goals. There is no one-size-fits-all megaregion. Geography and context matter.

\subsection{Frailties: critical issues in megaregional research}

1.3.1 Geographical excursions: a spiky world of megaregions, a spiky world of megaregion interest

The world's 40 largest mega-regions ... cover only a tiny fraction of the habitable surface of the earth and are home to less than $18 \%$ of the world's population; yet, they are responsible for $66 \%$ of global economic activity and about $85 \%$ of technological and scientific innovation. (Florida et al., 2008, p. 474)

The scale and pace of China's urbanization promises to continue at an unprecedented rate. If current trends hold, China's urban population will expand 
from 572 million in 2005 to 926 million in 2025 and hit the one billion mark by 2030. In 20 years, China's cities will have added 350 million people - more than the entire population of the United States today. By 2025, China will have 219 cities with more than one million inhabitants - compared with 35 in Europe today - and 24 cities with more than five million people. (McKinsey Global Institute, 2009, p. 1)

The two quotes refer to the 'spiky world' in which the megaregion debate is often situated. The first, by Richard Florida and his colleagues, provides a global overview a somewhat placeless idiom of geographical concentration which is often found quoted in the pages of glossy publications produced by prominent national and international organizations to extoll the virtues of megaregional urban growth (see Parsons Brinckerhoff, 2012; UN-Habitat, 2010a, 2010b). With such upbeat endorsements of the potency of large-scale agglomeration economies it is hardly surprising that the next step involves mapping where these megaregional spaces are located globally and providing a snapshot of what a megaregional world / world of megaregions might look like (Florida et al., 2008, 2012) ${ }^{3}$. By virtue of being a snapshot in time, this approach masks the dynamism which the second quote alludes to. McKinsey Global Institute show, in population terms, the dynamic geographical gravitation in interest from developments occurring in the United States to the extraordinarily rapid urbanization underway in China. Indeed, this brings us to our second point. As much as there is a spiky world of megaregions, there is also a spiky world of megaregion interest.

If we look back over the past century what we see are some remarkably clear periodizations of megaregional interest. Each periodization is characterized by the 
particular geographical focus and agenda which precipitated a growing interest in analysing large-scale urban forms. For instance, we have already noted how during the first half of the 20th century the putative megaregional research which emerged from Europe - Geddes and his contemporaries - was heavily influenced by ecological and environmentalist concerns and critiqued urban sprawl; then, during the 1960s, the analytical gaze switched to the United States with Gottmann's modernist and progressive view of the new urban form sparking a North American dominated interest in the concept of megaregions. We pick the story up in the 1980s with the acceleration of globalization. At this time the focus had returned to Western Europe, and France in particular. France laid the foundations for the European Spatial Development Perspective (ESDP) when it convened a meeting of spatial planning and regional development ministers from across the European Community in 1989 (Faludi and Waterhout, 2002). Alongside this, $\mathrm{DATAR}^{4}$ commissioned a team of researchers led by a geographer, Roger Brunet, to study the position of French territory in its European context. The study identified a discontinuous urbanized corridor of industrial growth running from northern England to northern Italy which it called the economic dorsale ('backbone') of Europe (Brunet, 1989). Bypassing Paris and excluding most of France, what became known as Europe's 'blue banana' provided a clear political statement. The French authors believed that in their national politics there had been excessive centralization of activity and investment in Paris. Their riposte was to argue that in an enlarged Europe, where the political-economic focus was gravitating to the east following the accession of post-socialist countries (see Taylor and Hoyler, 2000), Paris and the majority of French territory could no longer be seen as part of Europe's economic core. Nevertheless, the ESDP revamped the dorsale into a 'pentagon' and 
positioned it as a global economic integration zone - in effect, a megaregion - delimited by the cities of London-Paris-Milan-Munich-Hamburg (Commission of the European Communities, 1999).

The analytical gaze shifted further east in the 1990s in recognition of the rapid urbanization underway in southeast Asia in general, and China in particular (McGee and Robinson, 1995) ${ }^{5}$. This was the time when envious eyes were increasingly cast towards the mega-city regional growth economies of the Pearl and Yangtze River Deltas. This is relevant because the 'mega-city region' approach - the 'mega-city' and its 'region' - is a distinctly southeast Asian phenomenon, determined by city population and the sprawling urban form (Hall, 1999; Xu and Yeh, 2011). This is significantly different from a 'global city-region' - 'global city' and its region - where external and internal functional linkages are the determining attribute (Hall, 2001). Megaregions could be read as the attempt to weave the population-inspired mega-city region and functionallydominated global city-region concepts together. Certainly there is some evidence to suggest this.

Through the work of North American scholars and the RPAs America 2050 initiative the United States is seen as leading the megaregion assault, proactively responding to what they arguably see as the emergence of a megaregional world. Yet we would argue that this work is more reactive than proactive. Citing prominent European writers on European Spatial Development Planning practices - Faludi and Waterhout (2002), Jensen and Richardson (2001) - Ross is clear in the opening salvo to her book Megaregions - Planning for Global Competitiveness that 'such planning has set the stage for a more competitive Europe' meaning it is crucial for economic development practitioners in the United States to examine the 'usefulness of the 
megaregion and spatial planning in an American context' (Ross, 2009, p. 3). Likewise, the RPA is explicit in justifying how their focus on megaregions largely results from what 'our competitors in Asia and Europe' are doing (America 2050, 2013).

What this points towards is significant because it returns us to that fundamental question - why megaregions? Our answer rests in the importance of recognizing that different spatial concepts gained traction in different geographical contexts and at different times. Prominent spatial concepts are those which endure and have salience in a range of contexts. What marks megaregions out from other spatial concepts presently is that for the first time in its history the megaregion has become a truly global concept. Against the backdrop of the European Spatial Development Perspective and rapid urbanization underway in southeast Asia, championing by its North American promoters, and increasing prominence in other contexts (see UN-Habitat, 2010a, 2010b, on the Global South; Pieterse, 2010, on Africa; Weller and Bolleter, 2013, on Australia), what makes the megaregion stand out from other spatial concepts is the enthusiasm it has generated internationally among academics, policymakers and political leaders alike. The broader question this raises is why? More pointedly it encourages us to ask what role globalization is playing, and whether megaregions do constitute globalization's new urban form?

1.3.2 From the visible to the invisible: examining megaregion form and function A central tenet of megaregional research is the desire and need to define, designate and delimit megaregional space. It cannot be overlooked that 'to govern [or plan] it is necessary to render the visible space over which government is to be exercised. This is 
not simply a matter of looking: space has to be represented, marked out' (Thrift, 2002, p. 205). Marking out space is a deeply political act and the case of megaregions is no different. Our argument here is that this political act begins when researchers choose to prioritize megaregional form or megaregional function as their entry point. Prioritizing megaregional form leads researchers to start marking out space through observing what is visible in the physical landscape (e.g. urban sprawl), whereas those who prioritize megaregional function often begin by identifying what is less visible - even invisible in the physical landscape (e.g. flows of knowledge and capital). The result is very different mappings of megaregional space and megaregionality. To illustrate this we offer two contrasting examples of how megaregional space is being marked out.

The first approach is adopted by what we might call the 'North American school of megaregionalists'. Here the approach has been for researchers to consistently mark out megaregional space by taking spatial form as their starting point (Carbonell and Yaro, 2005; Florida et al., 2008; Lang and Knox, 2009; Nelson and Lang, 2011) ${ }^{6}$. In each case the result has been, first, to designate a smaller number of larger urbanregional economic units as globalization's new urban form. In this way it is a very spatially-selective approach, with only a minority (approximately $15-25$ per cent) of the population designated as being included within one of these megaregional spaces. But perhaps more significantly, cartographic representations of megaregional space almost always present these spaces as uniform (Figure 1.3). As a consequence there is an unwitting tendency for form-dominated approaches to infer and/or assume the functional coherence of the megaregional spaces they identify (cf. Burger and Meijers, 2012; Schafran, 2014, 2015). 
Figure 1.3 A form-dominant cartographic representation of megaregional space $* * *$ Insert Figure 1.3 here $* * *$

Source: $\quad$ Florida et al., 2008, p. 470. Reproduced by permission of RightsLink / Oxford University Press.

This brings us to the second group - what we might tentatively call the 'European School of megaregionalists' - who adopt a functionally-dominated approach to marking out megaregional space. Following Sassen's (1991) identification of advanced producer service firms as crucial actors and outcomes of deeper globalization and localization processes, the starting point for these researchers is the premise that the economic connections and information flows of business service firms provide 'a strategic lens to examine the intercity relations within larger urban regions and beyond defined city-regional boundaries, nationally and transnationally' (Hoyler et al., 2008b, p. 1055 original emphasis). This approach is perhaps most synonymous with the research produced as part of the POLYNET project ${ }^{7}$ which saw researchers from across Western Europe examine the functional geography of large-scale urban regions. In contrast to form-dominated cartographic representations of megaregional space, functionally-dominant cartographic representations are able to account for the unevenness of megaregionality processes within the megaregional spaces they identify (Figure 1.4). Moreover, the point we wish to stress is that prioritizing megaregional function over megaregional form has the potential to reveal megaregional spaces which although not appearing to be 'megaregional' in their physical manifestation - and by virtue of this automatically closed off from consideration within form-dominant approaches - do actually 'punch-above-their-weight' and act in a way which 
increasingly resembles processes of megaregionality. For sure these 'imagined' (Nelles, 2012) or im verborgenen ('secret' or 'hidden') (Thierstein et al., 2006) megaregional spaces may be small in agglomeration terms but the economic connections and information flows they have engendered through embedding business services firms ensure they are functionally integrated with the global economy (for a prominent example see Thierstein et al., 2008 on northern Switzerland).

Figure 1.4 A function-dominant cartographic representation of megaregional space $* * *$ Insert Figure 1.4 here $* * *$

Source: $\quad$ Hall and Pain, 2006, p. 85. Copyright (C) 2006 Earthscan. Reproduced by permission of Taylor \& Francis Books UK.

We think this prompts the urgent need for megaregional research to examine in which space-times form-dominant and functionally-dominant megaregional spaces are complementary, overlapping, competing or contradictory. This will require researchers to increasingly confront searching questions around whether form-first and functionfirst approaches are complementary in specific geographical contexts and to consider what the implications are - both academically, for the explanatory power of the megaregion concept, and practically, for planning and governance at the scale of megaregions - in places where they are (not).

1.3.3 Imagined megaregions? Megaregional space, spaces of the megaregion 
Over the past fifteen years the normative assumption that bigger equals more competitive has undoubtedly fuelled a search for a smaller number of larger urban economic units to be championed and lauded as being part on an increasingly exclusive club at the apex of the global urban hierarchy (see Figure 1.2). One way this has been achieved is the emergence of new urban-economic units which aggregate two or more single urban systems into one larger (megaregional) urban system. We only have to look at the names of the emerging megaregions to see examples of this. Of the 40 megaregions identified by Florida et al. (2008), 24 have conjoined names to designate a megaregion constructed from combining two or more urban systems into a larger, single urban system (e.g. Houston and New Orleans become 'Hou-Orleans'). In this section we seek to extend the discussion about form/functional dominance in megaregion research to begin asking what, if anything, makes these megaregions coherent as economic, but also political, cultural and institutional spaces? To answer this question we suggest two levels of analysis are required.

The first is a macro-level analysis of megaregional space and involves examining which urban systems have been aggregated to form these larger 'megaregional' urban systems and assessing their coherence as a single space. Our own respective research on global city-regions and mega-city regions has highlighted how, on a smaller scale, the evidence suggests that just because two urban systems are located proximate to each other does not mean they can be aggregated up to form a single, larger, more coherent and more competitive urban-economic unit. To take one example, Liverpool and Manchester are UK cities located less than $50 \mathrm{~km}$ apart. As single urban systems they do not have the critical mass to register as a global city-region à la Scott (2001a, 2001b) nor compare favourably with international competitors. Yet 
together they have a population of 6 million, making the single urban-region comparable to the RhineRuhr in Germany (5.3 million), the Rhône-Alpes in France (6.1 million) and the Randstad in the Netherlands (7.5 million). Part and parcel of what Jonas (2013, p. 289) recently referred to as 'internationally-orchestrated cityregionalism', certain policy elites mobilized in the late 2000s to advance the case for bolstering competitiveness by politically constructing a single, globally competitive urban space. Nonetheless, evidence pointed to their being 'no tangible' integration between the two cities and stakeholders failed to 'recognize' the geography (Harrison, 2014). What this alerts us to is a pressing need to assess the functional coherence of megaregional space. While we do not deny that some megaregional spaces are more coherent than others, we do question the coherence of some purported megaregions and mega urban corridors.

The second is a micro-level analysis of megaregional space. We start from a position which acknowledges that there is an unevenness of megaregionality processes across megaregional space (Sassen, 2007). From the financial district to the suburbs, the parking lot to the shopping mall, the middle-classes to the working-classes, the importance attached to this more localized level of analysis is the need to better understand how processes of megaregionality impact different spaces, places and people unevenly across megaregional space. A guiding question for future megaregional research is (how) does the megaregion concept help in understanding the quite different processes that are played out in these more localized spaces? In this way, Schafran's (2014) distinction between 'megaregional space' and 'spaces of the megaregion' helps us to identify those spaces where megaregionality is more or less important. While we think this is very useful, we would extend this further to include a temporal dimension. 
This has the advantage of not only providing a snapshot of where megaregionality is at its strongest or weakest within megaregional space but has the capacity to identify local spaces, places and people for whom processes of megaregionality are a dominant force, a formerly dominant and now declining force, or a newly emerging force.

We think this is particularly important because it provides a starting point for considering what we ultimately believe to be one of the most pressing concerns for megaregional analysis - the geopolitics of megaregionalism. First and foremost, the two levels of analysis we advocate above are capable of allowing researchers to reveal which areas and social groups are included or excluded from megaregionalism as a geopolitical project. More significantly, it creates the analytical lens necessary to begin to answer the question of megaregionalism, by whom, for whom? For sure, we urgently need more systematic examination of who is determining how megaregionalism is constructed politically, why - and specifically, in whose interests - megaregionalism is being mobilized, and how actors seek to defend and enhance their essential interests through megaregionalism. Ultimately this is a question of governance.

\subsubsection{Whose megaregion is it?}

With all the hysteria surrounding megaregions over the past decade it is perhaps unsurprising to note how few researchers have stopped to ask who is making this noise. This is not to say that researchers have not mentioned the groups involved - in fact, there are few accounts which fail to variously mention America 2050, the Regional Plan Association and the ESDP - rather it is to suggest that this is the extent of their interrogation of who is involved in promoting megaregions. Only a few writers have 
lingered long enough to consider the critically important questions: Which voices are being heard (the loudest) in the megaregion debate? What do these actors stand to gain from megaregions? Which voices are not being heard? Are certain voices being deliberately excluded (if so, why)? Who decides which voices are heard? These are the key questions we argue need to be at the heart of a more critical analysis of megaregions.

The rise of the megaregion has been underpinned by a strong geoeconomic logic. The rhetoric surrounding megaregions is undeniably one of economic boosterism supported by neoliberal pro-growth models of how economic development and competitiveness is to be achieved in our rapidly changing global economy. In this way it is unsurprising that powerful interest groups - federal and state governments, business and industry leaders, private investment groups, property and real-estate developers have been prepared to form alliances to extract value from planning at the scale of megaregions. There is a strong argument that powerful actors mobilize in support of the megaregion concept only where they see the potential for planning at this scale to defend and enable their essential interests to be realized. This could be national government decisions on which high-speed rail routes to prioritize for funding, the location and/or expansion of major national infrastructure sites, or the competition between container terminals to be key docking points for post-Panamax cargo vessels. What is significant about this in the context of the megaregion is that at this scale these decisions have moved from the multi-million pound infrastructure investments commonly associated with planning at the metropolitan scale, to the multi-billion investment decisions which were traditionally the sole domain of national politics. Simply put, the stakes are now higher than ever. 
One practical illustration of this is the close connection between the Regional Plan Association's America 2050 programme and the US Department of Transportation. It is no secret that much of the support for work on the megaregion concept came from the US Department of Transportation, for whom the megaregion is a vehicle through which they can raise the profile of what they see as the benefits of high-speed rail for economic development. The megaregion concept enables the department to secure the backing of key business leaders, investment groups and state officials to present a stronger business case on the need for more federal investment in high-speed rail and rail passenger capacity. Furthermore, the megaregion framework allows the Department of Transportation to lobby more vociferously on a national scale, therefore increasing the likelihood that they can win (some of) the arguments necessary to deliver one of their key political goals. With this in mind it is not surprising they were prepared to fund the academic research on megaregions necessary to develop this stronger business case for high-speed rail and increased rail passenger capacity. But by virtue of this the focus has been almost exclusively on issues of transportation ${ }^{8}$. Indeed, the only megaregion planning to emerge has related to specific policy spheres: there is no evidence of genuine economic development strategies in the traditional sense.

All of which places the spotlight on what, if anything, megaregions mean for other actors, particularly those whose voice is often not heard so loudly? In other words, what traction does the megaregion concept have among other stakeholder groups? One such area is sustainability which is currently receiving increased attention. There are those who, on the one hand, see coordinating economic development on the scale of megaregions as presenting opportunities to take a more strategic view on nationally significant planning decisions - land and resource issues, high-speed rail networks, 
transition to a low-carbon economy through large-scale investment in non-renewables production plants (e.g. industrial scale wind farms). On the other hand, there are those who oppose planning on the megaregional scale because it is perceived to be the extreme antithesis of the need to move towards more local and sustainable communities. Here the focus is on leading simpler, lower consumption, lifestyles, where energy production is decentralized to the scale of the household / community, supporting local business is prioritized over global corporations, and slower-speed modes of transportation (walking, bicycles, public transit) take precedent over the clamour for ever faster-modes (larger freeways, more high-speed rail, grater airport capacity). Research is already beginning to examine the potential contribution of megaregions to economic development and the objective of smart, sustainable, and inclusive growth (Benner and Pastor, 2011; Fleming, 2015; Marull et al., 2013; Ross et al., 2015; Wheeler, 2009, 2015).

If examining who is involved in promoting megaregions - and what they stand to gain - is one way of moving towards a more critical analysis of megaregions, a second way is to consider which geographical areas are included, on the fringes or excluded from the discursive framing of megaregions. Once again we return to the question of how megaregions are constructed geopolitically. Three examples elucidate our thinking on this point. First, Faludi (2009) points to the geopolitical construction of the ESDPs 'Pentagon' as an example of how policy elites configured this spatial imaginary to ensure a catchy 20-40-50 tagline (20 per cent of EU territory, 40 per cent of the EU population, 50 per cent of EU GDP generated) could be used as a branding and marketing tool for economic boosterism. 
Second, the definition used by Lang and Dhavale (2005) to identify 'megapolitan regions' from US Census data is that to be included regions must combine at least two metropolitan areas and have a total population of 10 million residents by 2040. What is interesting to note is that out of the ten megapolitan regions they identify, eight already had over 10 million residents by the year 2000 - so why 2040 ? Might it be that there was a need to alter the definition to ensure the two remaining regions Cascadia and Valley of the Suns - which do not currently have 10 million residents, were captured and included within the discursive frame? Off the map by standard criteria, certainly there is a long-standing argument to suggest this might be the case (see Harrison, 2010; Hoyler et al., 2006). Cascadia, for example, has a resident population of 7.5 million but it is arguably the strongest political advocate of large-scale economic cross-border regions. Supported by secession activists who campaign for Cascadian independence, Cascadia has one of the strongest cultural identities and movements (cf. Fleming, 2015), as well as a resident population of over 10 million if you take into account areas located beyond the US national border that are within the cultural region. They therefore represent a powerful political voice and their inclusion within the discursive frame of megaregions has some politico-cultural merits. Similarly for the Valley of the Sun (or Arizona Sun Corridor), which, although only having a resident population of 5 million, is a rapidly expanding regional growth economy. So capturing successful regional economies within the framing of megapolitan regions / megaregions clearly has its merits.

The third example requires us to look at how international organizations such as UN-Habitat (the United Nations Human Settlements Programme) have captured the concept of megaregions to advance their own particular political message and 
aspirations. UN-Habitat offer a revealing insight into the geopolitical construction of different megaregion discourses because in their annual State of the World's Cities Report for 2010-11 they not only gave prominent billing to megaregions, they constructed a very particular discourse around the development opportunities megaregions offered countries across the Global South (UN-Habitat, 2010a). What is striking about this report is although their map identifies megaregions and mega-urban corridors in North America and Europe, these spaces were excluded from the narrative. The narrative, reflected most clearly in the press release which accompanied the report's publication, is exclusively constructed around the development potential afforded by megaregions in southeast Asia, South America, and Africa (UN-Habitat, 2010b). From these examples what we see is that understanding how the megaregion concept is constructed to fit particular stories is a crucial, yet somewhat under-researched, dimension of megaregional research.

\subsection{Futures: megaregions as globalization's new urban form?}

Our ambition for embarking on this project has been to prompt more critical analyses of megaregions, megaregionality and the megaregion concept. By setting out to provide an introduction to what we hope will become a wider debate on megaregions, we have encouraged contributors to be more provocative than they may otherwise be in their academic writing. To facilitate this we asked authors to specifically address three questions in their chapters: 
- How robust are the foundations upon which the megaregion concept has been constructed?

- What are the methodological challenges of researching megaregions?

- Do megaregions constitute 'globalization's new urban form'? If not, are there alternative (more suitable) spatial frameworks?

Linking these central themes is the argument that in order to advance intellectual and practical debates on megaregions, attention needs to be focused on the who, the how and the why of megaregions much more than the what and the where of megaregions. Our aim is to move the debate forward from questions of definition, identification and delimitation to questions of agency (who or what is constructing megaregions), process (how are megaregions being constructed) and specific interests (why are megaregions being constructed); something which, we argue, requires a more political and more historical perspective on megaregions (Harrison and Hoyler, 2015). 


\section{References}

Agnew, J. (2013), ‘Arguing with regions', Regional Studies, 47 (1), 6-17.

Allen, J., D. Massey and A. Cochrane (1998), Rethinking the Region, London:

Routledge.

America 2050 (2008), 'U.S. megaregions with areas of incluence', available at http://www.america2050.org/pdf/2050_Map_Megaregions_Influence.pdf (accessed 25 September 2013).

America 2050 (2013), 'Megaregions', available at http://www.america2050.org/content/megaregions.html (accessed 25 September 2013). Baigent, E. (2004), 'Patrick Geddes, Lewis Mumford and Jean Gottmann: divisions over "megalopolis", Progress in Human Geography, 28 (6), 687-700.

Benner, C. and M. Pastor (2011), 'Moving on up: regions, megaregions, and the changing geography of social equity organizing', Urban Affairs Review, 47 (3), 315348.

Brenner, N. (2013a), 'Theses on urbanization', Public Culture, 25 (1), 85-114.

Brenner, N. (ed.) (2013b), Implosions/Explosions: Towards a Study of Planetary Urbanization. Berlin: Jovis.

Brenner, N. and C. Schmid (2011), 'Planetary urbanisation', in M. Gandy (ed.), Urban Constellations, Berlin: Jovis, pp. 10-13.

Brunet, R. (1989), Les Villes Europeénnes: Rapport pour la DATAR, Paris: La Documentation Française.

Burger, M. and E. Meijers (2012), 'Form follows function? Linking morphological and functional polycentricity', Urban Studies, 49 (5), 1127-1149. 
Carbonell, A. and R.D. Yaro (2005), 'American spatial development and the new megalopolis', Land Lines, 17 (3), 1-4.

Castree, N., R. Kitchin and A. Rogers (2013), A Dictionary of Human Geography, Oxford: Oxford University Press.

Chesterton, G.K. (1905), Heretics, London: Lane.

Commission of the European Communities (1999), European Spatial Development Perspective: Towards Balanced and Sustainable Development of the Territory of the $E U$, Luxembourg: Office for Official Publications of the European Communities.

Dewar, M. and D. Epstein (2007), 'Planning for "megaregions" in the United States', Journal of Planning Literature, 22 (2), 108-124.

Dühr, S. (2007), The Visual Language of Spatial Planning: Exploring Cartographic Representations for Spatial Planning in Europe, London: Routledge.

Faludi, A. (2009), 'The megalopolis, the blue banana, and global economic integration zones in European planning thought', in C.L. Ross (ed.), Megaregions: Planning for Global Competitiveness, Washington, DC: Island Press, pp. 18-34.

Faludi, A. and B. Waterhout (2002), The Making of the European Spatial Development Perspective: No Masterplan, London: Routledge.

Fleming, B. (2015), 'Towards a megaregional future: analysing progress, assessing priorities in the US megaregion project', in J. Harrison and M. Hoyler (eds), Megaregions: Globalization's New Urban Form? Cheltenham, UK and Northampton, MA, USA: Edward Elgar, pp. 220-229.

Florida, R. (2008), Who's Your City? How the Creative Economy is Making Where to Live the Most Important Decision of Your Life, New York: Basic Books. 
Florida, R., T. Gulden and C. Mellander (2008), 'The rise of the mega-region', Cambridge Journal of Regions, Economy and Society, 1 (3), 459-476.

Florida, R., C. Mellander and T. Gulden (2012), 'Global metropolis: assessing economic activity in urban centers based on nighttime satellite images', The Professional Geographer, 64 (2), 178-187.

Forbes (2011), ‘A city of 260 million - where else but China?' Forbes [online], 4 November, available at http://www.forbes.com/sites/megacities/2011/04/11/a-city-of260-million-where-else-but-china/ (accessed 24 September 2013).

Friedman, T. (2005), The World is Flat, New York: Farrar, Straus and Giroux. Geddes, P. (1915), Cities in Evolution: An Introduction to the Town Planning Movement and to the Study of Civics, London: Williams \& Norgate.

Glaeser, E. (2011), Triumph of the City, Oxford: Pan Books.

Gottmann, J. (1957), 'Megalopolis or the urbanization of the Northeastern Seaboard', Economic Geography, 33 (3), 189-200.

Gottmann, J. (1961), Megalopolis: The Urbanized Northeastern Seaboard of the United States, New York: Twentieth Century Fund.

Gottmann, J. (1976), 'Megalopolitan systems around the world', Ekistics, 41 (243), 109113.

Gottmann, J. and R. Harper (eds) (1990), Since Megalopolis: The Urban Writings of Jean Gottmann, Baltimore, MD: Johns Hopkins University Press.

Gregory, D., R. Johnston, G. Pratt, M. Watts and S. Whatmore (eds) (2009), The Dictionary of Human Geography (5th edition), Chichester: Wiley-Blackwell. Halbert, L., F.J. Convery and A. Thierstein (eds) (2006), 'Special issue: Reflections on the polycentric metropolis', Built Environment, 32 (2), 109-218. 
Hall, P. (1999), 'Planning for the mega-city: a new eastern Asian urban form?', in J. Brotchie, P. Newton, P. Hall and J. Dickey (eds), East West Perspectives on 21 st Century Urban Development: Sustainable Eastern and Western Cities in the New Millennium, Aldershot: Ashgate, pp. 3-36.

Hall, P. (2001), 'Global city-regions in the twenty-first century', in A.J. Scott (ed.), Global City-Regions: Trends, Theory, Policy, Oxford: Oxford University Press, pp. 5977.

Hall, P. and K. Pain (eds) (2006), The Polycentric Metropolis: Learning from MegaCity Regions in Europe, London: Earthscan.

Harrison, J. (2007), 'From competitive regions to competitive city-regions: a new orthodoxy, but some old mistakes', Journal of Economic Geography, 7 (3), 311-332. Harrison, J. (2010), 'Networks of connectivity, territorial fragmentation, uneven development: the new politics of city-regionalism', Political Geography, 29 (1), 17-27. Harrison, J. (2014), 'Rethinking city-regionalism as the production of new nonstate spatial strategies: the case of Peel Holdings Atlantic Gateway strategy', Urban Studies, 51 (11), 2315-2335.

Harrison, J. and M. Hoyler (2014), 'Governing the new metropolis', Urban Studies, 51 (11), 2249-2266.

Harrison, J. and M. Hoyler (2015), 'Megaregions reconsidered: urban futures and the future of the urban', in J. Harrison and M. Hoyler (eds), Megaregions: Globalization's New Urban Form? Cheltenham, UK and Northampton, MA, USA: Edward Elgar, pp. 230-255.

Harvey, D. (2000), Megacities Lecture 4: Possible Urban Worlds, Amersfoort: Twynstra Gudde Management Consultants. 
Hecksher, A. (1964), 'Foreword', in J. Gottmann, Megalopolis: The Urbanized Northeastern Seaboard of the United States, Cambridge, MA: MIT Press, pp. vii-viii. Hoyler, M., T. Freytag and C. Mager (2006), 'Advantageous fragmentation? Reimagining metropolitan governance and spatial planning in Rhine-Main', Built Environment, 32 (2), 124-136.

Hoyler, M., R.C. Kloosterman and M. Sokol (eds) (2008a), 'Special issue:

Globalization, city-regions and polycentricity in north-west Europe', Regional Studies, 42 (8), pp. 1055-1217.

Hoyler, M., R.C. Kloosterman and M. Sokol (2008b), 'Polycentric puzzles - emerging mega-city regions seen through the lens of advanced producer services', Regional Studies, 42 (8), 1055-1064.

Jensen, O. and T. Richardson (2001), 'Nested visions: new rationalities of space in European spatial planning', Regional Studies, 35 (8), 703-717.

Jonas, A.E.G. (2013), 'City-regionalism as a contingent "geopolitics of capitalism"”, Geopolitics, 18 (2), 284-298.

Kunzmann, K. (1996), 'Euro-megalopolis or themepark Europe? Scenarios for European spatial development', International Planning Studies, 1 (2), 143-163. Lang, R.E. and D. Dhavale (2005), 'Beyond Megalopolis: exploring America’s new megapolitan geography', Metropolitan Institute Census Report Series, 05:01, Alexandria, VA: The Metropolitan Institute at Virginia Tech.

Lang, R.E. and P.L. Knox (2009), ‘The new metropolis: rethinking megalopolis', Regional Studies, 43 (6), 789-802.

McGee, T.G. and I.M. Robinson (eds) (1995), The Mega-Urban Regions of Southeast Asia, Vancouver: UBC Press. 
McKinsey Global Institute (2009), Preparing for China's Urban Billion - Summary of Findings. McKinsey \& Company.

Marull, J., V. Galletto, E. Domene and J. Trullén (2013), 'Emerging megaregions: a new spatial scale to explore urban sustainability', Land Use Policy, 34 (1), 353-366. Meller, H. (1993), 'Some reflections on the concept of megalopolis and its use by Patrick Geddes and Lewis Mumford', in T. Barker and A. Sutcliffe (eds), Megalopolis: The Giant City in History, New York: St. Martin's Press, pp. 116-129.

Morrill, R. (2006), 'Classic map revisited: the growth of megalopolis', The Professional Geographer, 58 (2), 155-160.

Mumford, L. (1938), The Culture of Cities, New York: Harcourt.

Nelles, J. (2012), Metropolitan Governance and Policy: Governing Beyond Local Boundaries in the Imagined Metropolis, London: Routledge.

Nelson, A.C. and R.E. Lang (2011), Megapolitan America: A New Vision for Understanding America's Metropolitan Geography, Chicago, IL: APA Planners Press. OECD (2006), Competitive Cities in the Global Economy, OECD Territorial Reviews, Paris: Organisation for Economic Co-operation and Development.

Pain, K. and G. Van Hamme (eds) (2014), Changing Urban and Regional Relations in a Globalizing World: Europe as a Global Macro-Region, Cheltenham, UK and Northampton, MA, USA: Edward Elgar.

Parsons Brinckerhoff (2012), The Future of Cities and Urban Infrastructure, New York: Parsons Brinckerhoff.

Pieterse, E. (2010), 'The mega-regions of Africa in global perspective', The Global Urbanist, 24 March 2010, available at http://globalurbanist.com/2010/03/24/the-megaregions-of-africa-in-global-perspective (accessed 25 September 2013). 
Reades, J. and D.A. Smith (2014), 'Mapping the "space of flows": the geography of global business telecommunications and employment specialization in the London mega-city-region’, Regional Studies, 48 (1), 105-126.

Regional Plan Association (2006), America 2050: A Prospectus, New York: RPA. Ross, C.L. (ed.) (2009), Megaregions: Planning for Global Competitiveness, Washington, DC: Island Press.

Ross, C.L., D. Lee, E. Meijers and T. Welch (2015), Megaregions, Prosperity and Sustainability, London: Routledge.

Sassen, S. (1991), The Global City: New York, London, Tokyo, Princeton, NJ: Princeton University Press.

Sassen, S. (2007), 'Megaregions: benefits beyond sharing trains and parking lots?', in K.S. Goldfeld (ed.), The Economic Geography of Megaregions, Princeton, NJ: The Policy Research Institute for the Region, pp. 59-83.

Sayer, A. (1992), Method in Social Science: A Realist Approach, London: Routledge. Schafran, A. (2014), 'Rethinking mega-regions: sub-regional politics in a fragmented metropolis', Regional Studies, 48 (4), 587-602.

Schafran, A. (2015), 'Beyond globalization: a historical urban development approach to understanding megaregions', in J. Harrison and M. Hoyler (eds), Megaregions: Globalization's New Urban Form? Cheltenham, UK and Northampton, MA, USA: Edward Elgar, pp. 75-96.

Scott, A.J. (2001a), 'Globalization and the rise of city-regions', European Planning Studies, 9 (7), 813-826.

Scott, A.J. (ed.) (2001b), Global City-Regions: Trends, Theory, Policy, Oxford: Oxford University Press. 
Short, J.R. (2007), Liquid City: Megalopolis and the Contemporary Northeast, Washington, DC: Resources for the Future.

Taylor, P.J. and M. Hoyler (2000), 'The spatial order of European cities under conditions of contemporary globalisation', Tijdschrift voor Economische en Sociale Geografie, 91 (2), 176-189.

Taylor, P.J. and R.E. Lang (2004), 'The shock of the new: 100 concepts describing recent urban change', Environment and Planning A, 36 (6), 951-958.

Taylor, P.J., D.M. Evans, M. Hoyler, B. Derudder and K. Pain (2009), 'The UK space economy as practised by advanced producer service firms: identifying two distinctive polycentric city-regional processes in contemporary Britain', International Journal of Urban and Regional Research, 33 (3), 700-718.

Thierstein, A., C. Kruse, L. Glanzmann, S. Gabi and N. Grillon (2006),

Raumentwicklung im Verborgenen: Die Entwicklung der Metropolregion Nordschweiz, Zürich: Verlag Neue Zürcher Zeitung.

Thierstein, A., S. Lüthi, C. Kruse, S. Gabi and L. Glanzmann (2008), 'Changing value chain of the Swiss knowledge economy: spatial impact of intra-firm and inter-firm networks within the emerging mega-city region of northern Switzerland', Regional Studies, 42 (8), 1113-1131.

Thrift, N. (2002), 'Performing cultures in the new economy', in P. Du Gay and M. Pryke (eds), Cultural Economy, London: Sage, pp. 201-234.

UN-Habitat (2010a), State of the World's Cities 2010/2011: Bridging the Urban Divide, Nairobi: UN-Habitat.

UN-Habitat (2010b), 'Urban trends: urban corridors - shape of things to come?', UNHabitat Press Release, 13 March, Nairobi: UN-Habitat. 
Vicino, T., B. Hanlon and J.R. Short (2007), 'Megalopolis, 50 years on: the transformation of a city region', International Journal of Urban and Regional Research, 31 (2), 344-367.

Weller, R. and J. Bolleter (2013), Made in Australia: The Future of Australian Cities, Perth: University of Western Australia Publishing.

Wheeler, S.M. (2009), 'Regions, megaregions, and sustainability', Regional Studies, 43 (6), 863-876.

Wheeler, S.M. (2015), 'Five reasons why megaregional planning works against sustainability', in J. Harrison and M. Hoyler (eds), Megaregions: Globalization's New Urban Form? Cheltenham, UK and Northampton, MA, USA: Edward Elgar, pp. 97118.

Xu, J. and A.G.O. Yeh (eds) (2011), Governance and Planning of Mega-City Regions: An International Comparative Perspective, London: Routledge.

Yang, J. (2009), 'Spatial planning in Asia: planning and developing megacities and megaregions', in C.L. Ross (ed.), Megaregions: Planning for Global Competitiveness, Washington, DC: Island Press, pp. 35-52.

Zhang, X. (2015), 'Globalization and the megaregion: investigating the evolution of the Pearl River Delta in a historical perspective', in J. Harrison and M. Hoyler (eds), Megaregions: Globalization's New Urban Form? Cheltenham, UK and Northampton, MA, USA: Edward Elgar, pp. 175-199. 
Table 1.1

\begin{tabular}{|c|c|c|c|c|c|c|}
\hline Concept & Definition & $\begin{array}{l}\text { Minimum } \\
\text { population }\end{array}$ & $\begin{array}{l}\text { Maximum } \\
\text { population }\end{array}$ & Geography & Number & $\begin{array}{l}\text { Foundational } \\
\text { literature }\end{array}$ \\
\hline Megalopolis & $\begin{array}{l}\text { "[V]ery large polynuclear urbanized systems } \\
\text { endowed with enough continuity and internal } \\
\text { interconnections for them to be considered a } \\
\text { system in itself." (Gottmann, 1976, p. 162) }\end{array}$ & 25 million & $\begin{array}{l}\text { Not } \\
\text { specified }\end{array}$ & $\begin{array}{l}\text { Northeastern } \\
\text { United States }\end{array}$ & 1 & Gottmann (1961) \\
\hline
\end{tabular}




\begin{tabular}{|c|c|c|c|c|c|c|}
\hline $\begin{array}{l}\text { Metro(politan) } \\
\text { regions }\end{array}$ & $\begin{array}{l}\text { "[L]arge concentrations of population and } \\
\text { economic activity that constitute functional } \\
\text { economic areas, typically covering a number of } \\
\text { local government areas. An economic area in } \\
\text { this sense denotes a geographic space within } \\
\text { which a number of economic links are } \\
\text { concentrated." (OECD, 2006, p. 31) }\end{array}$ & 1.5 million & 34 million & OECD & 78 & OECD (2006) \\
\hline $\begin{array}{l}\text { Planetary } \\
\text { urbanization }\end{array}$ & $\begin{array}{l}\text { "[E]ven spaces that lie well beyond the } \\
\text { traditional city cores and suburban peripheries } \\
\text { - from transoceanic shipping lanes ... [to] } \\
\text { erstwhile 'natural' spaces such as the world's } \\
\text { oceans, deserts, jungles, mountain ranges, }\end{array}$ & $\mathrm{n} / \mathrm{a}$ & 7 billion + & Global & 1 & $\begin{array}{l}\text { Brenner (2013a, } \\
\text { 2013b); Brenner } \\
\text { and Schmid (2011) }\end{array}$ \\
\hline
\end{tabular}


tundra, and atmosphere - have become integral

parts of the worldwide urban fabric" (Brenner

and Schmid, 2011, p. 13)

${ }^{\mathrm{i}}$ The largest megaregion of 121.6 million is Pearl River Delta. It is worth noting that back in 2009 it was reported that plans were afoot to expand the region politically so the population of the Pearl River Delta would reach 260 million (Forbes, 2011).

Source: Authors 
Figure 1.2

\begin{tabular}{|c|c|c|c|}
\hline $\begin{array}{c}\text { ENTIRE GLOBAL URBAN } \\
\text { SYSTEM }\end{array}$ & & Planetary urbanization & \\
\hline $\begin{array}{c}\text { 2+ INTERRELATED URBAN } \\
\text { SYSTEMS }\end{array}$ & & Megaregion & \\
\hline SINGLE URBAN SYSTEM & Global city-region & Mega-city region & Metro(politan) region \\
\hline
\end{tabular}

Source: Authors 
${ }^{1}$ August Hecksher was Director of The Twentieth Century Fund who had funded much of Gottmann's research into urbanization of megalopolis.

${ }^{2}$ Here we are also reminded of a quote by the English writer G.K. Chesterton, who in his 1905 book Heretics commented that 'Nothing more strangely indicates an enormous and silent evil of modern society than the extraordinary use which is made nowadays of the word "orthodoxy" ... The word 'orthodoxy' not only no longer means being right; it practically means being wrong' (pp. 11-12).

${ }^{3}$ Here we are making this distinction to emphasise our belief that we live in a world with, not of, megaregions. 'Megaregional world' is where the onus is on the importance of megaregions shaping the world we live in, that is, there is something fundamental connecting megaregions to globalization. We prefer 'world of megaregions' because this recognizes that while we live in a world where there are megaregions and processes of megaregionality this is not to say there is something fundamental connecting megaregions to globalization.

${ }^{4}$ DATAR is the French Interministerial Delegation for Regional Planning and Regional Attractiveness. It was set up by President Charles de Gaulle in the 1960s to promote the development of French regions as a counterbalance to Paris. When Jacques Chirac, a former mayor of Paris, became Prime Minister, then later President of France, DATAR's raison d'être lost its political influence. Its future existence was founded on conceptualizing French territory in the fast evolving European context (Faludi, 2009).

${ }^{5}$ It would be remiss not to acknowledge that this mega-city regional literature extended beyond southeast Asia to include many accounts of similar processes occurring across parts of Latin America and Africa. 
${ }^{6}$ This is not to say there is a uniform approach - one only has to look in the United States at the epistemological differences between megaregionalists, who concentrate on traditional urban-regional planning concerns, and megapolitanists, whose focus is on interpreting US Census data (Fleming, 2015) - rather it is to highlight how this approach is qualitatively different from the more functionally-dominant approach which has been central within European debate.

${ }^{7}$ POLYNET (or "POLYNET: Sustainable Management of European Polycentric MegaCity Regions" to give its full title) was a $€ 2.4$ million research project funded by the European Regional Development Fund under the INTERREG IIIB North West Europe programme between 2003-2006. The aim was to examine changes in functional connections and information flows (physical/transportation and virtual/ICT) in eight major urban regions across North West Europe: South East England, the Paris Region, Central Belgium, the Randstad, Rhine-Main, RhineRuhr, Northern Switzerland and Greater Dublin. The principal project outcomes are reported in Hall and Pain (2006), Halbert et al. (2006) and Hoyler et al. (2008a).

${ }^{8}$ You only have to look at the America 2050 website (http://www.america2050.org/) to see the predominance of transportation issues in the debate over megaregions in the United States. 